\title{
Phylogenetic Analysis of Low-Pathogenicity Avian Influenza H6N2 Viruses from Chicken Outbreaks (2001-2005) Suggest That They Are Reassortants of Historic Ostrich Low-Pathogenicity Avian Influenza H9N2 and H6N8 Viruses
}

\author{
C. Abolnik, ${ }^{\mathrm{AB}}$ S. P. R. Bisschop, ${ }^{\mathrm{C}}$ G. H. Gerdes, ${ }^{\mathrm{A}}$ A. J. Olivier, ${ }^{\mathrm{D}}$ and R. F. Horner ${ }^{\mathrm{EF}}$

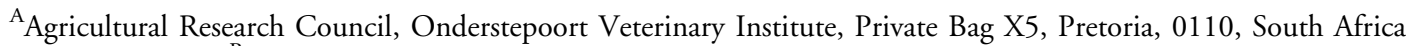 \\ ${ }^{\mathrm{B}}$ Department of Zoology, University of Pretoria, Pretoria, 0002, South Africa \\ ${ }^{C}$ Poultry Reference Laboratory,University of Pretoria, Pretoria, 0002, South Africa \\ D Klein Karoo Group, Ostrich Laboratory, P.O. Box 241, Oudtshoorn, 6620, South Africa \\ ${ }^{\mathrm{E}}$ Allerton Provincial Veterinary Laboratory, 458 Town Bush Road, Montrose, Pietermaritzburg, 3201, South Africa \\ ${ }^{\mathrm{F}}$ Vetdiagnostix Laboratory, P.O. Box 13624, Cascades, Pietermaritzburg, 3202, South Africa
}

Received 31 March 2006; Accepted 29 August 2006

\begin{abstract}
SUMMARY. Low-pathogenicity (LPAI) and high-pathogenicity (HPAI) avian influenza viruses are periodically isolated from South African ostriches, but during 2002 the first recorded outbreak of LPAI (H6N2) in South African chickens occurred on commercial farms in the Camperdown area of KwaZulu/Natal (KZN) Province. Sequence analysis of all eight genes were performed and phylogenetic analysis was done based on the hemagglutinin and neuraminidasc sequences. Results from phylogenetic analyses indicated that the H6N2 chicken viruses most likely arose from a reassortment between two South African LPAI ostrich isolates: an H9N2 virus isolated in 1995 and an H6N8 virus isolated in 1998. Two cocirculating sublineages of H6N2 viruses were detected, both sharing a recent common ancestor. One of these sublineages was restricted to the KZN province. The neuraminidase gene contained a 22-amino acid deletion in the NA-stalk region, which is associated with adaptation to growth in chickens, whereas the other group, although lacking the NA-stalk deletion, spread to commercial farms in other provinces. The persistence of particular H6N2 types in some regions for at least 2 yr supports reports from Asia and southern California suggesting that H6N2 viruses can form stable lineages in chickens. It is probable that the ostrich H6N8 and H9N2 progenitors of the chicken H6N2 viruses were introduced to ostriches by wild birds. Ostriches, in which AI infections are often subclinical, may serve as mixing vessels for LPAI strains that occasionally spill over into other poultry.
\end{abstract}

RESUMEN. El análisis filogenético de los virus H6N2 de influenza aviar de baja patogenicidad provenientes de un brote en pollos (2001-2005) sugiere que son una recombinación de dos virus de influenza aviar de baja patogenicidad H9N2 y H6N8 de avestruz.

Virus de influenza aviar de baja y alta patogenicidad son aislados periódicamente de avestruces en Sur África, pero durante el año 2002 en granjas comerciales del área de Camperdown en la provincia de KwaZulu/Natal se registró el primer brote de influenza aviar de baja patogenicidad (H6N2) en pollos de Sur África. Se realizó el análisis de la secuencia de todos los ocho genes y el análisis filogenético se hizo basado en la secuencia de los genes que codifican para la hemaglutinina y la neuraminidasa. Los resultados de los análisis filogenéticos indican que los virus de pollo H6N2 muy probablemente surgieron de la recombinación entre dos aislamientos Surafricanos de influenza aviar de baja patogenicidad: un H9N2 aislado en el año 1995 y un H6N8 aislado en el año 1998. Se detectaron dos sublinajes de H6N2 circulando, ambos con un ancestro común. Uno de los sublinajes estaba restringido a la provincia de KwaZulu/Natal. El gen de la neuraminidasa contenía una deleción de 22 aminoácidos en la región del tallo de la proteína, lo cual se asocia con la adaptación a crecer en pollos, mientras el otro grupo, aunque carecía de la deleción en la proteína neuraminidasa, se diseminó a granjas comerciales en otras provincias. La persistencia durante al menos dos años de un tipo particular de H6N2 en algunas de las regiones, apoyan reportes de Asia y del sur de California que sugieren que los virus H6N2 pueden formar linajes estables en pollos. Es probable que los progenitores del virus H6N2 de pollo (H6N8 y H9N2 de avestruz) fueran introducidos en los avestruces por aves silvestres. Las avestruces, donde las infecciones con influenza aviar son comúnmente subclínicas, pueden servir como huéspedes intermediarios para cepas de influenza aviar de baja patogenicidad que ocasionalmente se transmiten a otros tipos de aves domésticas.

Key words: avian influenza virus, H6N2, ostriches, reassortment, phylogenetic analysis

Abbreviations: $\mathrm{AI}=$ avian influenza; $\mathrm{AIV}=$ avian influenza virus; $\mathrm{HPAI}=$ high pathogenicity avian influenza; $\mathrm{KZN}=\mathrm{KwaZulu} /$ Natal; LPAI = low pathogenicity avian influenza; NA = neuraminidase; RT-PCR $=$ reverse transcription-polymerase chain reaction

In South Africa, low-pathogenicity avian influenza (LPAI) has historically been a sporadic wintertime disease of intensively farmed ostriches. From these birds, LPAI H7N1 was isolated in 1991, H5N9 in 1994 , H9N2 in 1995 , H6N8 in 1998, and H10N1 in 2001. The first South African outbreak of high-pathogenicity avian influenza (HPAI), caused by an $\mathrm{H} 5 \mathrm{~N} 2$ strain, caused clinical illness and increased mortalities in ostriches of the Eastern Cape province in 2004 (13) and the first recorded outbreak of avian influenza (AI) in South African chickens occurred in 2002. That June, layers at a large commercial operation in the Camperdown region of the KwaZulu/
Natal (KZN) province developed symptoms of respiratory distress and up to $40 \%$ declines in egg production. An orthomyxovirus was isolated and determined to be an LPAI H6N2 strain at the Veterinary Laboratory Agency, Weybridge Laboratory, United Kingdom. Most outbreaks of AI in domestic poultry are thought to have originated by the transfer of viruses from feral birds $(1,5)$. Chickens are generally not considered to be natural hosts for AI viruses (AIVs) and $\mathrm{H} 6$ viruses have never been associated with mass mortalities in poultry. However, it has been suggested that H6 viruses may be capable of developing stable lineages in chickens (10), 
and several $\mathrm{H} 6 \mathrm{~N} 1$ and $\mathrm{H} 6 \mathrm{~N} 2$ outbreaks have been recorded in recent years in southeastern Asia and in California $(2,15,17)$.

The South African H6N2 outbreak, which affected only commercial chickens, continued throughout 2003 and sporadically in 2004, and an inactivated H6N2 vaccine was applied to limit the spread of the disease. Testing of archival material from the Camperdown region traced the infection back to June 2001, but the exact source of the H6N2 outbreak strain was never determined. During 2005, low-level infections of H6 AIVs were detected in chicken and dove organ samples that were concomitantly infected with Newcastle disease virus, and in the organs of ostriches from the Western Cape province. This paper describes phylogenetic relationships between South African H6N2 strains collected since 2001, their genetic relationships to a 1995 South African H9N2 ostrich virus, a 1998 South African H6N8 ostrich virus, and other important molecular characteristics of these viruses.

\section{MATERIALS AND METHODS}

Viruses. Homogenates of organs from infected birds were inoculated into the allantoic cavity of 10-day-old embryonated chicken eggs. Hemagglutinating agents were tested for and AIVs were identified by specific hemagglutination inhibition with H6-specific AI antisera and by reverse transcription-polymerase chain reaction (RT-PCR) of the matrix protein gene by the PCR diagnostic laboratory (unpubl. data). Fortysix AI isolates collected from June 2001 to November 2005 were analyzed in this study. Neuramidase (NA) inhibition tests were performed according to the OIE Reference Laboratory procedure to determine the $\mathrm{N}$ type of the $2005 \mathrm{H} 6$ virus isolates.

RNA extraction and RT-PCR. Viral RNA was extracted from allantoic fluid using TRIzol ${ }^{\circledR}$ reagent (Gibco, Invitrogen, Johannesburg), or with the QIAamp Viral RNA mini kit (Qiagen, Southern Cross Biotechnology, Johannesburg), according to the manufacturer's instructions. Full-length AIV genes were amplified according to the methods and oligonucleotide primer pairs described by Hoffman et al. (6), except for the HA genes that were amplified using forward and reverse oligonucleotide primers for which sequences were kindly provided by D. Suarez. PCR was preceded by reverse transcription using M-MLV reverse transcriptase (Promega, Whitehead Scientific, Johannesburg) at $42 \mathrm{C}$ for $90 \mathrm{~min}$ on $5 \mu \mathrm{l}$ of extracted viral RNA, using the same forward and reverse primers used for PCR.

Gene sequencing. PCR products were purified with the QIAquick ${ }^{\circledR}$ gel extraction kit (Qiagen), and quantified with a NanoDrop ${ }^{\circledR}$ ND-1000 spectrophotometer (NanoDrop Technologies, Inc. ). BigDye ${ }^{\circledR}$ Terminator V3.1 chemistry (Perkin Elmer/Applied Biosystems) and the gene-specific primers described above were used for cycle sequencing, according to the manufacturer's instructions. Reactions were run on a 3130 Genetic Analyzer (Applied Biosystems). The nucleotide sequence data reported in this paper have been submitted to the GenBank nucleotide sequence database and have been assigned the accession numbers DQ408506-DQ408529.

Phylogenetic analysis. Sequences were visualized with Chromas Lite 1.0 software (http://www.technelysium.com.au) and edited with BioEdit V.7.5.0.2 (4). BLAST homology searches (www.ncbi.nlm.nih. gov/blast) were used to retrieve the top 50 homologous sequences for each gene from the GenBank database. For the South African H6N2 HA genes, the region analyzed corresponds to nucleotides 838 to 954 (116 nucleotides) of the complete 1744-nucleotide coding region for H6 genes (9). The phylogenetic topology for the 116-nucleotide region is similar to that found in the full-length HA sequences of some South African H6N2 H6 genes (data not shown). The mapped distances based on partial sequences may not be representative of the complete genetic divergence of the genes, but the topology illustrates the general genetic relationship.

Multiple sequence alignments were prepared with ClustalW (http:// www.ebi.ac.uk/clustalw/index.html) and phylogenies were reconstructed with MEGA 3.1 software (8) using the neighbor-joining tree inference method, with 1000 bootstrap replicates to assign confidence levels to branches.

Potential N-glycosylated sites were predicted using the NetNGlyc 1.0 werver (http://www.cbs.dtu.dk/services/NetNGlyc/).

\section{RESULTS}

Comparison of the South African H6N2 chicken outbreak strains. Two distinct sublineages (I and II) of H6 AIV (Fig. 1) circulated during the South African outbreak in chickens from 2001 to 2005. Sublineage I viruses were isolated only at commercial operations in the KZN province, mostly in and around Camperdown. In one case, a particular strain, I(a), persisted in the town of Margate from the end of September 2003 (CKZA03AL33) throughout 2004 (CKZA04AL36) into March 2005 (CKZA05AL41). The ostrich virus OSZA03KK0727 (I[e]) is an outlier to sublineage I and was isolated in the Oudtshoorn region in September 2004. Sublineage II is a weakly supported group, but all the viruses of the latter clearly group together.

Sublineage II circulated over the same time period as sublineage I viruses but contains viruses isolated from both the KZN and Gauteng provinces. CKZA02UP855 (II[f]) was isolated in Pretoria in September 2002, and OSZA03N158 (II[g]) from ostriches near Johannesburg in March 2003. Analysis of the peptide sequences surrounding the NA stalk region (data not shown) indicated that sublineage I viruses all contained a 22-amino acid deletion in the stalk region, which was absent from sublineage II viruses.

The H6N2 viruses isolated from chickens, ostriches, and a dove from June to November 2005 (h) did not fall within lineages I and II as did the 2002 H6N2 outbreak strains. Instead, their H6 genes appeared to be more closely related to that of A/Ostrich/South Africa/KK98/98, the H6N8 virus isolated in Oudtshoorn in 1998. The possibility of laboratory contamination was ruled out.

To identify the source of the 2002 H6N2 chicken outbreak strains, a representative from sublineage I, A/Chicken/South Africa/ AL19/02 (H6N2) and one from sublineage II, A/Chicken/South Africa/UP1102/02 (H6N2), were selected for further comparison.

The origins of the H6N2 chicken virus genes. Phylogenetic analyses of the surface glycoprotein and internal genes of two chicken $\mathrm{H} 6 \mathrm{~N} 2$ and one ostrich $\mathrm{H} 6 \mathrm{~N} 8$ viruses were conducted. Fig. 2 indicates that A/Chicken/South Africa/AL19/ 2002 (CKZA02AL19) and A/Chicken/South Africa/UP1102/02 (CKZA02UP1102) share a recent common ancestor for their H6type hemagglutinin genes, and that this hypothetical gene appears to be derived from the 1998 ostrich H6N8 virus A/Ostrich/South Africa/KK98/98 (OSZA98KK98). Other H6 genes included in sublineage A include those of the H6N1 viruses, A/duck/Korea/S17/ 03 and A/duck/Hong Kong/3461/99, suggesting that the South African $\mathrm{H} 6$ genes have had recent common ancestors in east Asia, as did those of viruses in domestic turkeys from Germany and a wild mallard from the Netherlands from 1998 to 2003.

Fig. 3 indicates that the closest relative to A/Chicken/South Africa/AL19/02 and A/Chicken/South Africa/UP1102/02 NA genes is the N2 gene from A/Ostrich/South Africa/9508103/95 (H9N2), isolated in 1995 from ostriches in the Oudtshoorn region (sublineage B). Other less closely related N2 genes from sublineage B included $\mathrm{H} 9 \mathrm{~N} 2$ virus $\mathrm{N} 2$ genes from ducks in Hokkaido, Japan, sampled from 1997 to 2000.

Results for the phylogenetic comparison of the eight internal genes for A/Chicken/South Africa/AL19/02 (H6N2) and A/ Chicken/South Africa/UP1102/02 (H6N2) are presented elsewhere, but for all genes the two H6N2 chicken viruses shared a recent common ancestor. 


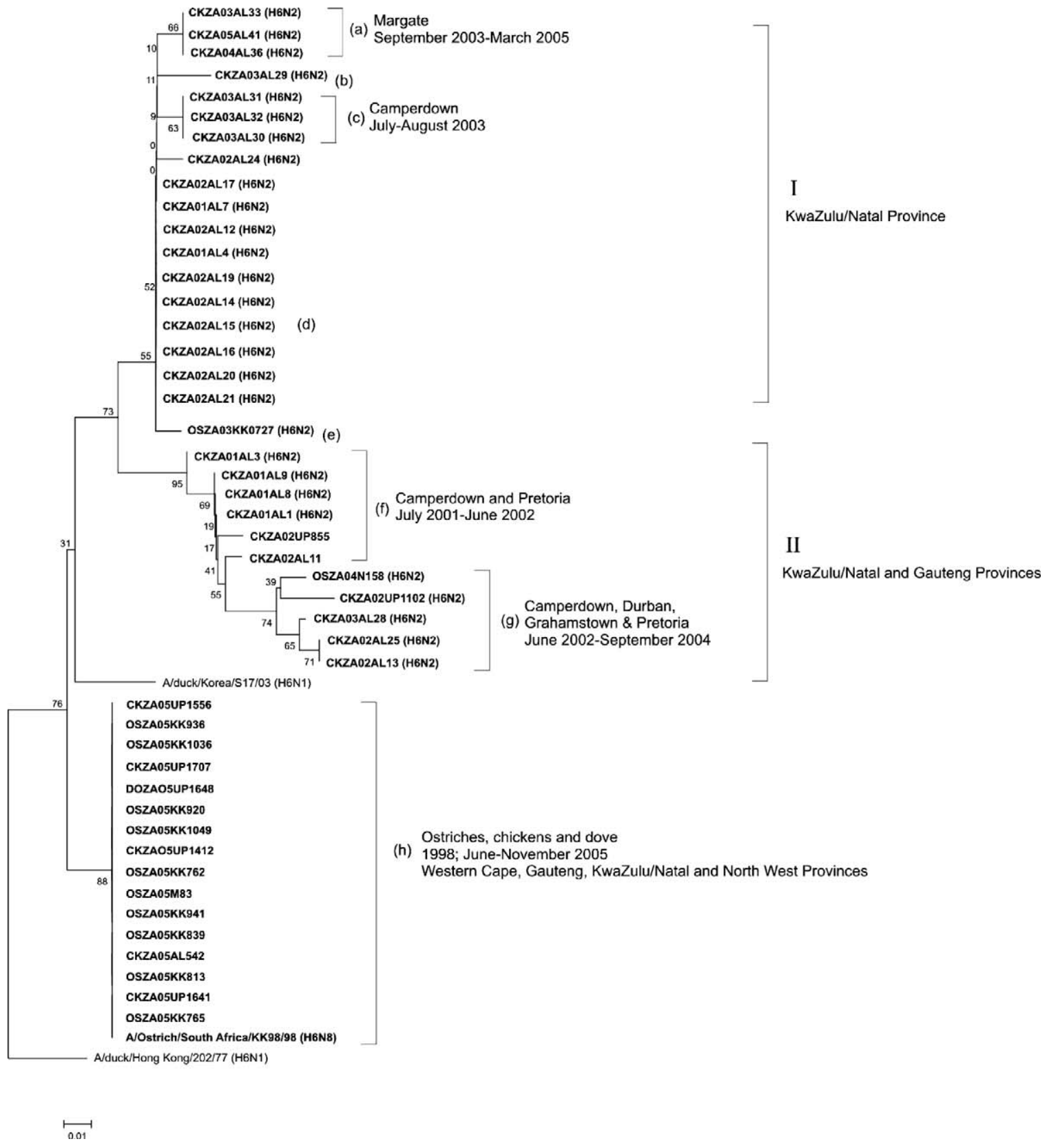

Fig. 1. Phylogenetic tree of the partial H6 HA nucleotide sequences. The tree is rooted with A/duck/Hong Kong/202/77 (H6N1). South African viruses isolated and sequenced in the present study are in boldface, and sublineages I and II and (a) to (h) are indicated. The names contain the following information: CK-ZA-03-AL28 = host-country-year-lab number; where CK = chicken, OS $=$ ostrich, and ZA $=$ South Africa.

Other molecular determinants of pathogenicity. The H6 peptide sequences were analyzed for potential N-glycosylation sites. Four N-glycosylation were predicted in A/Ostrich/South Africa/KK98/98 (positions 27, 39, 182, and 305), whereas A/ Chicken/South Africa/UP1102/02 had only three (positions 27, 39, and 311) and A/Chicken/South Africa/AL19/02, five (positions 27, 39, 170, 183, and 306). The peptide cleavage sites at $\mathrm{H}_{0}$ were determined to be ${ }^{339}$ PQIEPRGLR ${ }^{347}$ for both A/Chicken/South Africa/AL19 (H6N2) and A/Ostrich/South Africa/KK98/98 (H6N8), but ${ }^{339} \mathrm{PQIETRGLR}^{347}$ for A/chicken/South Africa/ UP1102/02 (H6N8). The HA peptide sequence of A/Chicken/ South Africa/AL19/02 (H6N2) contained the aspartic acid residue $\mathrm{D}^{144}$, whereas A/Chicken/South Africa/UP1102/02 (H6N2) had an asparagine residue similar to duck isolates. A/Ostrich/South Africa/ KK98/98 (H6N8) had a serine residue at this position, which was shared by isolates from ducks, turkeys, chickens and quail.

\section{DISCUSSION}

Phylogenetic results indicated that relatives common to two Oudtshoorn ostrich LPAI isolates, a $1995 \mathrm{H} 9 \mathrm{~N} 2$ virus (A/Ostrich/ South Africa/9508103) and a 1998 H6N8 virus, (A/Ostrich/South Africa/KK98/98), coinfected a host (an ostrich or a wild bird in the region), and that an $\mathrm{H} 6 \mathrm{~N} 2$ virus arose by reassortment. The H6N2 virus then spread to chickens but it is not clear when or how this occurred because ostrich and commercial poultry production are 


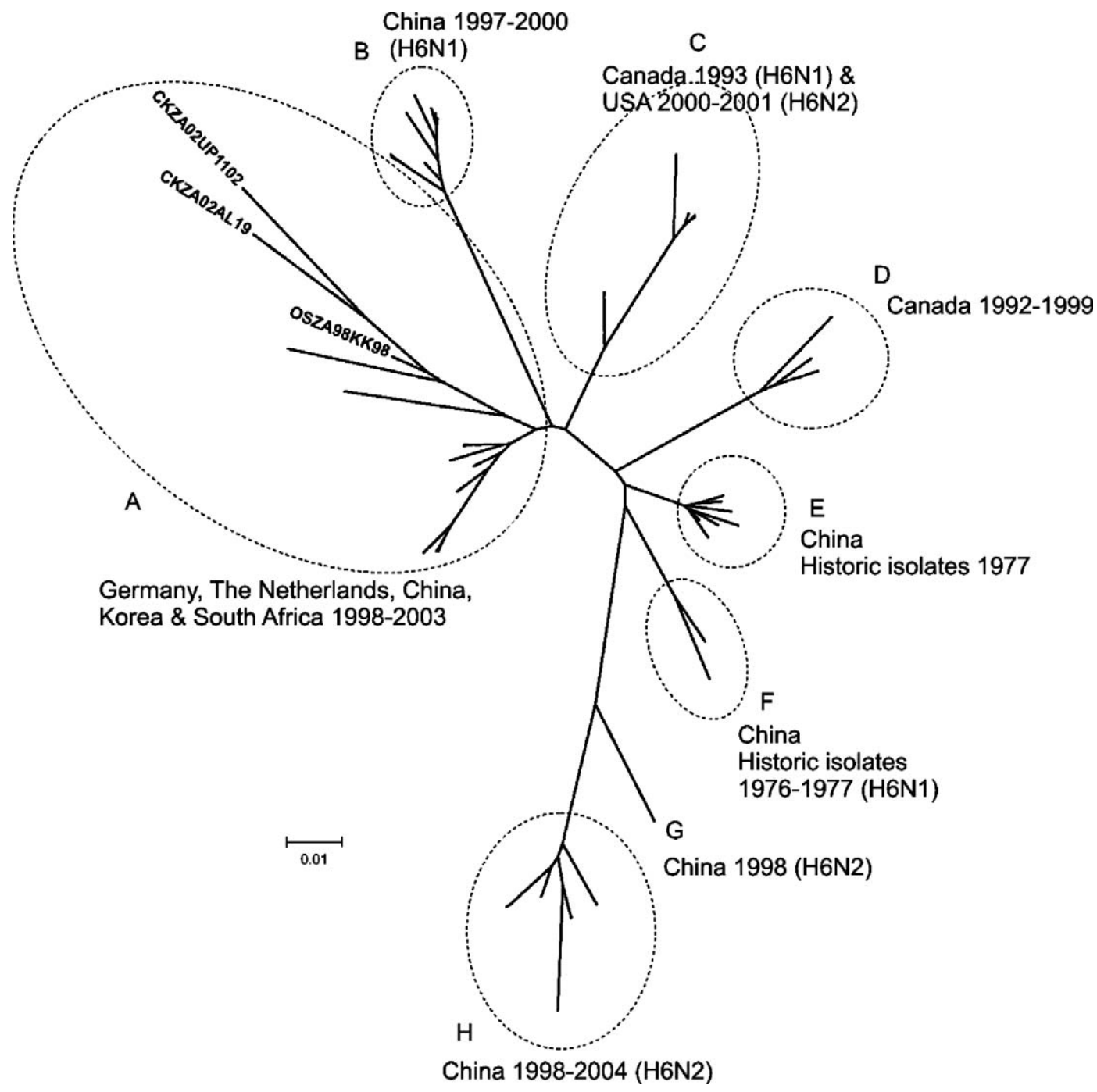

Fig. 2. Unrooted phylogenetic tree of the H6 HA nucleotide sequences (1367 nt). South African viruses isolated and sequenced in the present study are in boldface, and sublineages $\mathrm{A}$ to $\mathrm{H}$ are indicated.

separated by geographic and climatic boundaries. The H6N2 virus diverged into two separate sublineages, I and II, both of which were implicated in the 2002 Camperdown outbreak. From Camperdown in the KZN the infection spread to at least one other province (Gauteng) through the movement of infected birds. Intensified serological surveillance revealed that the outbreaks were restricted to commercial operations (unpubl. data). Both sublineages I and II circulated for roughly the same time periods, but sublineage I viruses contained multiple genetic markers associated with the adaptation of avian influenza viruses to chickens. Firstly, a 22-amino acid deletion in the stalk region of the NA gene was observed. The predicted sequence of the N2 NA protein of the six Californian H6N2 chicken viruses from 2000 to 2001 also contained a deletion in the stalk region, but the deletion was only 18 amino acids in length. No large deletions were found in the stalk regions of the aquatic birds sequenced in that study, indicating that the region may represent an adaptation for growth in chickens $(7,18)$. Secondly, several studies have indicated that certain mutations in the HA gene are able to compensate for a shortened NA stalk, including increased glycosylation near the receptor binding site, which decreases receptor binding affinity $(12,16)$. Sublineage I viruses displayed this hyperglycosylation, with five predicted $\mathrm{N}$-glycosylation sites in the HA gene compared to only three in those of sublineage II, that did not contain the NA-stalk deletion. Thirdly, the presence of $\mathrm{D}^{144}$, a proposed genetic marker that distinguishes terrestrial bird isolates from aquatic ones (2), was observed in the sublineage I HA gene. The adaptations in the HA and NA genes, combined with the example of a particular strain (Fig. 1, sublineage I[a]) persisting in a town for $3 \mathrm{yr}$, supports the findings of other investigators $(15,17,19)$ that $\mathrm{H} 6$ viruses are capable of forming stable lineages in chickens.

The most likely vectors for the introduction of AIV into the Western Cape ostrich population are the wild waterfowl with which the ostriches are in contact with because of their attraction to water and feed troughs; wild waterfowl also graze on ostrich pastures each winter. In fact, H6 antibodies were detected in the serum of wild ducks in the Oudtshoorn region during the winter of 1998 (14), around the same time that the H6N8 virus was isolated from the ostriches. There is mounting evidence that ratites exhibit atypical (for poultry) and often subclinical responses to infections with AIVs, even with HPAI strains $(3,11)$. Therefore, it is possible that mature ostriches could act as mixing vessels for strains of AIVs without showing clinical disease. The results of this paper indicate that LPAI viruses from ostriches potentially pose a threat to the poultry 


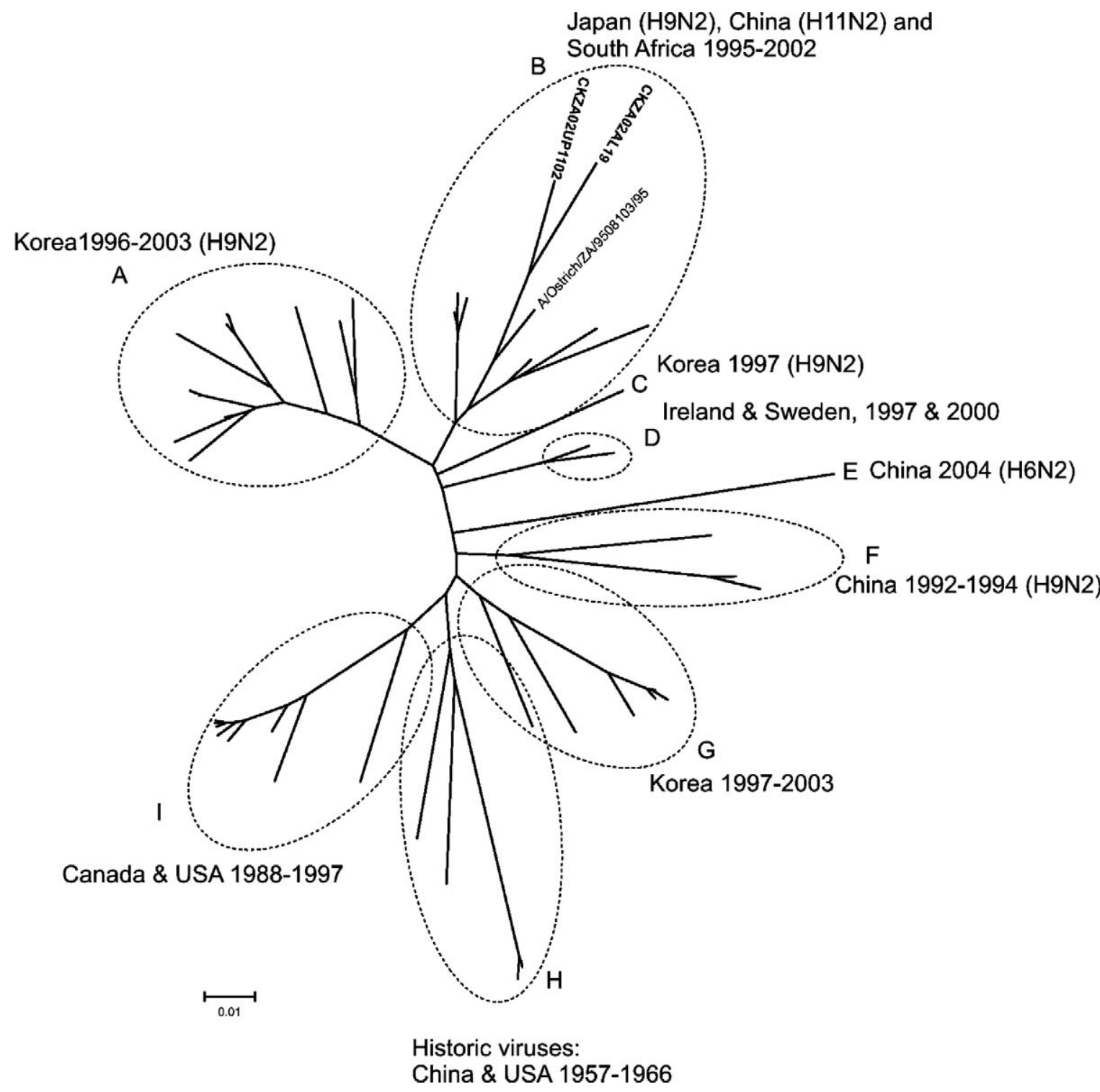

Fig. 3. Unrooted phylogenetic tree of the N2 neuraminidase nucleotide sequences (1104 nt). Deletions and insertions in the nucleotide sequence were removed to facilitate comparison. South African viruses isolated and sequenced in the present study are in boldface, and sublineages A to I are indicated.

industry if there is a breakdown in the implementation of biosecurity measures.

During 2005, more H6N2 viruses were isolated from ostrich, chicken, and dove organ samples from four of the nine provinces. Interestingly, the limited H6 gene sequences indicated that these viruses were phylogenetically very closely related to the A/Ostrich/ South Africa/KK98/98 rather than to the 2002 chicken viruses, but that the NA genes were N2 instead of N8, as indicated by NAinhibition tests. These preliminary findings strongly suggest that the progenitor H6N2 virus to sublineages I and II is still circulating in ostriches and/or poultry and further analysis of these viruses is continuing. If ostriches are potential long-term reservoirs of LPAI viruses in South Africa, as suggested by this study, it is important to continue to monitor their AIV gene pool. Furthermore, in the likelihood that HPAI H5N1 will be introduced into South Africa in the near future by migratory birds, ostriches could be an important sentinel species. The ecology of AIV in the ostrich host is an area in which research efforts will be concentrated in the future.

\section{REFERENCES}

1. Alexander, D. J., B. Dodet, and M. Vicari, eds. Ecology of avian influenza in domestic birds. In: Emergence and control of zoonotic orthoand paramyxovirus diseases. John Libbey Eurotext, Montrouge, France. pp. 25-34. 2001.

2. Chin, P. S., E. Hoffmann, R. Webby, R. G. Webster, Y. Guan, M. Peiris, and K. F. Shortridge. Molecular evolution of H6 influenza viruses from poultry in southeastern China: prevalence of H6N1 influenza viruses posessing seven A/Hong Kong/156/97 (H5N1)-like genes in poultry. J. Virol. 76(2):507-516. 2002.

3. Clavijo, A., J. Riva, and J. Pasick. Pathogenicity of a ratite-origin influenza A H5 virus in ostriches (Struthio camelus). Avian Dis. 47(3):12031207. 2003.

4. Hall, T. A. BioEdit: a user-friendly biological sequence alignment editor and analysis program for Windows 95/98/NT. Nucl. Acids Symp. 41: 95-98. 1999.

5. Halvorson, D., D. Karunakaran, D. Senne, C. Kelleher, C. Bailey, A. Abraham, V. Hinshaw, and J. Newman. Epizootiology of avian influenzasimultaneous monitoring of sentinel ducks and turkeys in Minnesota. Avian Dis. 27:77-85. 1983. 
6. Hoffmann, E., J. Stech, Y. Guan, R. G. Webster, and D. R. Perez. Universal primer set for the full-length amplification of all influenza A viruses. Arch. Virol. 146:2275-2289. 2001.

7. Kinde, H., D. H. Read, B. M. Daft, M. Hammarlund, J. Moore, F. Uzal, J. Mukai, and P. Woolcock. The occurrence of avian influenza A subtype H6N2 in commercial layer flocks in southern California (2000-02): clinicopathologic findings. Avian Dis. 47:1214-1218. 2003.

8. Kumar, S., K. Tamura, and M. Nei. MEGA3: integrated software for molecular evolutionary genetics analysis and sequence alignment. Briefings in Bioinformatics 5:150-163. 2004.

9. Lee, M. S., P. C. Chang, J. H. Shien, M. C. Cheng, and H. K. Shieh. Identification and subtyping of avian influenza viruses by reverse transcription-PCR. J. Virol. Methods 97(1-2):13-22. 2001.

10. Liu, M., Y. Guan, M. Peiris, S. He, R. J. Webby, D. Perez, and R. G. Webster. The quest of influenza A viruses for new hosts. Avian Dis. 47: 849-856. 2003.

11. Manvell, R. J., C. English, P. H. Jorgensen, and I. H. Brown. Pathogenesis of $\mathrm{H} 7$ influenza A viruses isolated from ostriches in the homologous host infected experimentally. Avian Dis. 47(3):1150-1153. 2003.

12. Matrosovich, M., N. Zhou, Y. Kawaoka, and R. G. Webster. The surface glycoproteins of $\mathrm{H} 5$ influenza viruses isolated from humans, chickens, and wild aquatic birds have distinguishable properties. J. Virol. 73:1146-1155. 1999.

13. Olivier, A. J. Ecology and epidemiology of avian influenza in ostriches. In: OIE/FAO Scientific Conference on Avian Influenza. A. Schudel and M. Lombard, eds. Karger, Basel, Switzerland. Dev. Biol. (Basel) 124:51-57. 2006.
14. Pfitzer, S., D. J. Verwoerd, G. H. Gerdes, A. E. Labuschagne, A. Erasmus, R. J. Manvell, and C. Grund. Newcastle disease and avian influenza A virus in wild waterfowl in South Africa. Avian Dis. 44:655660. 2000.

15. Suarez, D. L. Evolution of avian influenza viruses. Vet. Microbiol. 74(1-2):15-27. 2000.

16. Wagner, R., T. Wolff, A. Herwig, S. Pleschka, and H. D. Klenk. Interdependence of haemagglutinin glycosylation and neuraminidase as regulators of influenza virus growth: a study by reverse genetics. J. Virol. 74: 6316-6323. 2000.

17. Webby, R. J., P. R. Woolcock, S. L. Krauss, D. B. Walker, P. S. Chin, K. F. Shortridge, and R. G. Webster. Multiple genotypes of nonpathogenic H6N2 influenza viruses isolated from chickens in California. Avian Dis. 47(3):905-910. 2003.

18. Webby, R. J., P. R. Woolcock, S. L. Krauss, and R. G. Webster. Reassortment and interspecies transmission of North American H6N2 influenza viruses. Virology 295:44-53. 2002.

19. Woolcock, P. R., D. L. Suarez, and D. Kuney. Low-pathogenicity avian influenza virus (H6N2) in chickens in California, 2000-02. Avian Dis. 47(3):872-881. 2003.

\section{ACKNOWLEDGMENTS}

We wish to thank Ruth Manvell for resupplying a stock of the H6N8 virus; Margaret Parker, Raina Maharaj, Boto Ganzevoort, C. Mutlow, S. Abrahams, and Elsa Cornelius for excellent technical assistance; and Marco Romito and Phelix Majiwa for critical review of the manuscript. 